\title{
Toxicity Assessment of Synthetic Pyrethroids (Lambda Cyhalothrin) on the Liver and Kidney Organs of Male Wistar Rats
}

\author{
O. O. Fadina ${ }^{1}$, F. I. Oshoke ${ }^{1^{\star}}$ and O. O. Fayinminnu ${ }^{1}$ \\ ${ }^{1}$ Department of Crop Protection and Environmental Biology, Faculty of Agriculture and Forestry, \\ University of Ibadan, Nigeria.
}

Authors' contributions

This work was carried out in collaboration between all authors. Authors FIO, O. O. Fadina and O. O. Fayinminnu designed the study, performed the statistical analysis, wrote the protocol, wrote the first draft of the manuscript and managed the analyses of the study. Author FIO managed the literature searches. All authors read and approved the final manuscript.

Article Information

DOI: $10.9734 / A R R B / 2017 / 31906$

Editor(s):

(1) Paola Angelini, Department of Applied Biology, University of Perugia, Perugia, Italy.

(2) George Perry, University of Texas at San Antonio, USA.

Reviewers:

(1) Akpan, Akaninyene Udoh, University of Uyo, Nigeria. (2) Francis W. Hombhanje, Divine Word University, Papua New Guinea. Complete Peer review History: http://www.sciencedomain.org/review-history/19737

Original Research Article

Received $30^{\text {th }}$ January 2017

Accepted $25^{\text {th }}$ March 2017

Published $28^{\text {th }}$ June 2017

\section{ABSTRACT}

Aims: Humans and animals are occasionally and unintentionally exposed to lethal and sub lethal doses of pesticides stemming from its various uses to control pests both in agriculture, homes, gardens and public health. The use of pyrethroid products has grown and continues to grow due to the suspension of some organophosphorus and organochloride products. This current study evaluated the toxic effects of lambda-cyhalothrin (LCT) on hematological and histopathological changes in the liver and kidney organs of rats after sub chronic exposure.

Study Design: Completely randomized design (CRD) with 5 treatments replicated 5 times.

Place and Duration of Study: Department of Crop Protection and Environmental Biology, Faculty of Agriculture and Forestry, University of Ibadan, Nigeria, between July and August, 2015.

Methodology: Twenty-five 7-week-old male Wistar rats were randomly assigned to five groups. The control (group 1) received distilled water, while experimental groups 2, 3, 4 and 5 received by 
gavage 25, 50, 75 and $100 \mathrm{mg} / \mathrm{kg}$ body weight, respectively LCT over a period of five weeks. Hematological and histopathological studies were carried out on the blood and organs of interest, respectively on termination of the experiment.

Results: There was a dose-related reduction of white blood cell count from $3.25 \pm 0.22$ (control) to $3.00 \pm 0.62(100 \mathrm{mg} / \mathrm{kg})$, and severity in alteration of the micro anatomy of the liver and kidney with increase in LCT concentration in the treated animals. The results showed necrosis and vacuolar changes in the hepatocytes and congestion of interstitial blood vessels. Also observed was a significant change in the body weight of the wistar rats after the $5^{\text {th }}$ week of treatment with an average weight of $198 \mathrm{~kg}, 196 \mathrm{~kg}, 194 \mathrm{~kg}, 186 \mathrm{~kg}, 160 \mathrm{~kg}$ for control, $25 \mathrm{mg} / \mathrm{kg}, 50 \mathrm{mg} / \mathrm{kg}, 75 \mathrm{mg} / \mathrm{kg}$ and $100 \mathrm{mg} / \mathrm{kg}$ treatment respectively.

Conclusion: lambda-cyhalothrin is highly toxic (even at the lowest dose in this experiment) and may cause cell damage, organ failure, anaemic conditions and reduce immunity.

Keywords: Pyrethroid; hepatocytes; necrosis; toxicity; wistar rat; liver; kidney.

\section{INTRODUCTION}

Although pesticides have largely benefited the human life through enhancement of agricultural products and controlling infectious diseases, however, their extensive use in turn, has offended human health from occupational or environmental exposures [1]. Long-term contact to pesticides can harm human life and can disturb the function of different organs in the body, including nervous, endocrine, immune, reproductive, renal, cardiovascular and respiratory systems [1]. Pesticides constitute the most widespread environmental contaminants due to their ubiquitous use in all aspects of human endeavors. Pesticide residues are often reported in foods and known to gain entry into the human body through the consumption of such foods. The people who use pesticides or regularly come in contact with them must understand the relative toxicity and potential health risk associated with these pesticides. All directions, restrictions and precautions on pesticide labels should be observed. Also, pesticides should only be used when absolutely necessary.

Pyrethroids are derived from the naturally occurring pyrethrums, which in turn are the oleoresin extracts of dried chrysanthemum flowers. Their persistence in the environment is in the order of weeks, unlike organochlorines, which persist for years [2]. Insecticidal products containing pyrethroid have widely been used for pest control in agriculture, public health, homes and gardens [3]. In agriculture, cotton, cereal, hops, ornamentals, potatoes and vegetables are the target crops to control aphids, coleopterous and lepidopterous pests [4]. It is an important tool in public health management to control cockroaches, mosquitoes, ticks and flies, which can act as disease vectors.

Lambda-cyhalothrin (trade names Excaliber, Karate, Grenade, Lara force, Kombact, Warrior) penetrates the insect cuticle, disrupting nerve condition within minutes, this leads to loss of muscular control, paralysis and eventual death [5]. It was found that lambda-cyhalothrin is moderately toxic for mammals [6-8] Similar to other compounds from the pyrethroid family, the toxicity of lambda-cyhalothrin could vary depending on both its concentration and the nature of used solvent [9]. Adverse changes in liver and kidney tissues of test animals have also been observed on cypermethrin (pyrethroid) treated male rats [10].

Therefore, the use of lambda-cyhalothrin domestically and in agriculture necessitated the study of its toxicity. Due to its widespread use in agriculture and public health, the present study is aimed at assessing the toxicity following sub chronic exposure of sub lethal doses.

\section{MATERIALS AND METHODS}

\subsection{Experimental Materials}

A total of 25 individual male of Rattus norveigicus with weights ranged from 100-150 g were used for this study. Wistar rats were procured from the Animal House of the Department of Physiology, College of Medicine, University of Ibadan, Nigeria. The rats were acclimatized for three weeks before the commencement of the treatments. The rats were fed on growers mash throughout the duration of the study and the feed was purchased from a local agroshop. Water and feed were supplied ad libitum. All experimental 
animals were handled in accordance with the guidelines for care and use of laboratory animals.

\subsection{Dilution of Lambda-cyhalothrin (LCT) Pesticide}

The pesticide LCT was mixed with a vehicle (water). The concentration of the active ingredient in Kombat is $25 \mathrm{~g} / \mathrm{L}$ (on label), this is also equivalent to $25,000 \mathrm{mg} / \mathrm{L}$. A $2 \mathrm{mls}$ of the pesticide solution was taken and distilled water added to make it up to $500 \mathrm{~mL}$, this gave a solution of the active ingredient in 1,000 ppm. These concentrations were determined using the formula below as described by [11].

$$
\mathrm{C}_{1} \mathrm{~V}_{1}=\mathrm{C}_{2} \mathrm{~V}_{2}
$$

Where;

$$
\begin{aligned}
& \mathrm{C}_{1}=\text { initial concentration of stock } \\
& \mathrm{V}_{1}=\text { volume of stock used } \\
& \mathrm{C}_{2}=\text { desired concentration } \\
& \mathrm{V}_{2}=\text { desired volume }
\end{aligned}
$$

From this stock solution, the following treatments were taken and distilled water added to make it up to $250 \mathrm{~mL}$.

Treatment 4: $6.25 \mathrm{~mL}$ equivalent to $25 \mathrm{mg} / \mathrm{L}$ Treatment 3: $12.5 \mathrm{~mL}$ equivalent to $50 \mathrm{mg} / \mathrm{L}$ Treatment 2: $18.75 \mathrm{~mL}$ equivalent to $75 \mathrm{mg} / \mathrm{L}$ Treatment 1: $25 \mathrm{~mL}$ equivalent to $100 \mathrm{mg} / \mathrm{L}$

\subsection{Experimental Set Up/Toxicological Study}

The experiment was laid out in a completely randomized design (CRD) with 5 treatments replicated 5 times. The 25 Wistar rats were divided into 5 groups of 5 rats each. The various levels of the pesticide formed the treatment with a control group (no pesticide). The treatment levels were:

$$
\begin{aligned}
& \mathrm{T} 4=25 \mathrm{mg} / \mathrm{kg} \text { of LCT } \\
& \text { T3 }=50 \mathrm{mg} / \mathrm{kg} \text { of LCT } \\
& \text { T2 }=75 \mathrm{mg} / \mathrm{kg} \text { of LCT } \\
& \text { T1 }=100 \mathrm{mg} / \mathrm{kg} \text { of LCT }
\end{aligned}
$$

All doses (treatments) were administered daily (in the mornings) by oral gavage (with a $2 \mathrm{ml}$ syringe and cannula) for a period of five weeks. Animals were weighed weekly. At the end of the experiment, animals were sacrificed by cervical dislocations. The organs of interest (liver and kidney) were carefully dissected out and weighed.

\subsection{Data Collected}

The animals were weighed weekly in order to determine weight gain/loss also; The feed given was weighed in order to ascertain the daily feed intake. Physical observations such as shyness, behavioral pattern of the rats, signs of pesticide toxicity such as tremors, loss of appetite, muscle jerking, constricted pupils, vomiting etc. [12] were recorded per animal in each treatment.

\subsection{Histopathological Analysis}

On termination of the experiment, all the surviving Wistar rats were sacrificed and organs of interest (liver and kidney) were harvested via cervical dislocation. In preparing the animal tissues (liver and kidney) of each rat for microscopic examination, histological procedures were followed in a stepwise protocol thus: fixation, dehydration, clearing, infiltration, embedding, blocking, sectioning and staining [13-15].

\subsection{Statistical Analyses}

Data obtained from the study were subjected to one-way analysis of variance ANOVA (SAS Version 9.2, 2002; 2003), while group means were compared for significant differences at $95 \%$ confidence level $(p=.05)$ [16]. The results are presented as mean \pm standard error of the mean (SEM).

\section{RESULTS AND DISCUSSION}

\subsection{Behavioral/Morphological Responses}

All the rats were observed to rub their lip regions and faces with their fore limb after treatment administration. General loss of appetite was also noticed in all treated rats. Obvious behavioral response to pesticide toxicity (nasal discharge and paralyses) was evident amongst most of the LCT treated rats. A significant dose- dependent decrease in body weight was observed for rats treated with LCT when compared with control.

\subsection{Hematological and Serum Biochemistry Results Examination}

Results showed a significant dose dependent decrease in white blood cell count and hemoglobin with increase in concentration of LCT. Also the Eosinophil value for the control was significantly $(P=.05)$ lower than those of the 


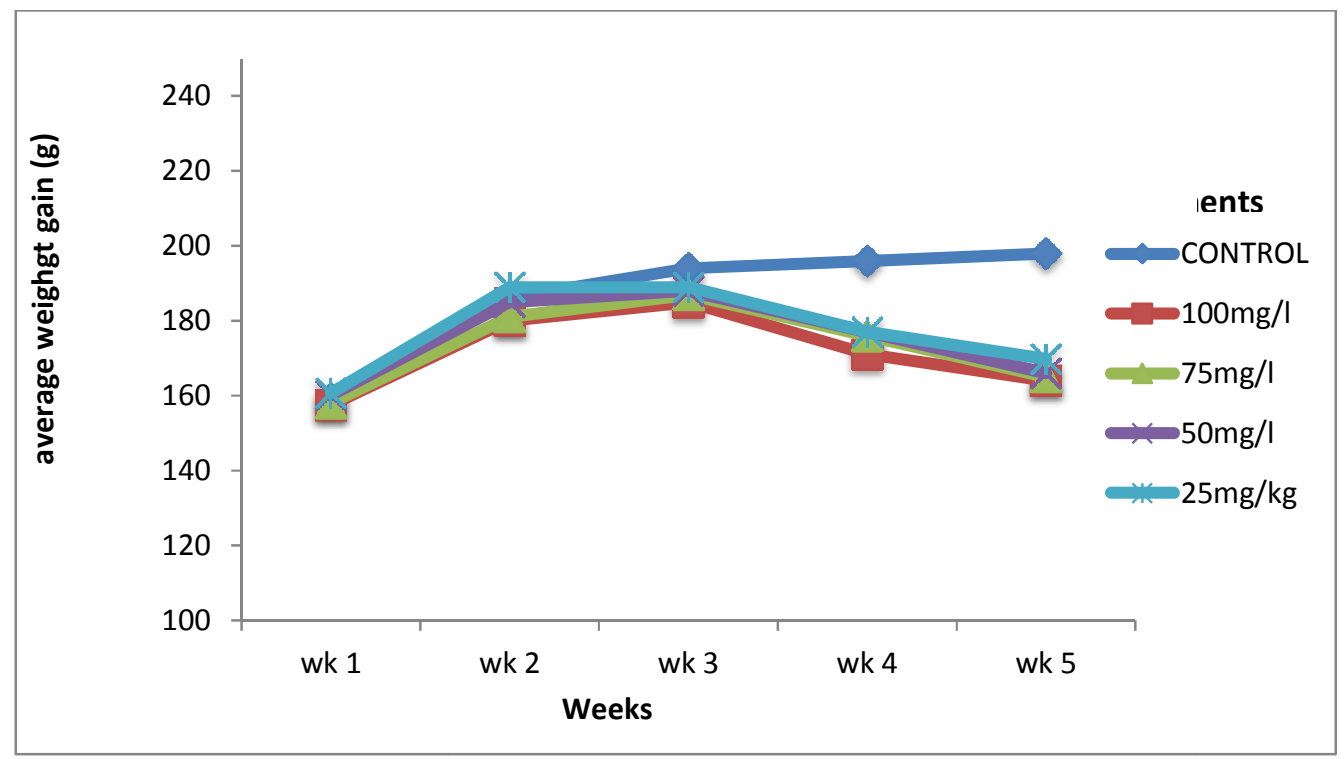

Fig. 1. Effects of varying concentrations of Lambda-cyhalothrin on average weight (g) of Rattus norvegicus

Table 1. Effects of varying concentrations of Lambda-cyhalothrin on blood sample parameters of wistar rats

\begin{tabular}{llllll}
\hline Treatments(mg/kg) & ALB & HB(g/d) & RBC(10 $\mathbf{~} \boldsymbol{\mu l})$ & WBC & Eosinopil(\%) \\
\hline 100 & $3.72 \pm 2.12 \mathrm{a}$ & $13.95 \pm 0.71 \mathrm{a}$ & $7.95 \pm 2.12 \mathrm{a}$ & $3.00 \pm 0.62 \mathrm{ab}$ & $4.20 \pm 0.87 \mathrm{a}$ \\
75 & $3.67 \pm 2.35 \mathrm{a}$ & $14.10 \pm 0.78 \mathrm{a}$ & $8.04 \pm 2.35 \mathrm{a}$ & $3.00 \pm 1.18 \mathrm{ab}$ & $4.50 \pm 0.65 \mathrm{a}$ \\
50 & $3.87 \pm 2.02 \mathrm{a}$ & $14.10 \pm 0.67 \mathrm{a}$ & $8.06 \pm 2.02 \mathrm{a}$ & $2.60 \pm 0.11 \mathrm{a}$ & $4.25 \pm 0.85 \mathrm{a}$ \\
25 & $3.75 \pm 2.95 \mathrm{a}$ & $14.55 \pm 0.98 \mathrm{a}$ & $8.11 \pm 2.95 \mathrm{a}$ & $2.70 \pm 0.35 \mathrm{a}$ & $3.55 \pm 0.48 \mathrm{a}$ \\
control & $3.65 \pm 0.50 \mathrm{a}$ & $15.3 \pm 0.17 \mathrm{~b}$ & $8.87 \pm 0.50 \mathrm{~b}$ & $3.25 \pm 0.22 \mathrm{~b}$ & $1.25 \pm 0.48 \mathrm{~b}$ \\
\hline
\end{tabular}

${ }^{*}$ Means within the same column followed by the same letter(s) are not significantly different at $P=.05$ using DMRT

$H B=$ Hemoglobin, $R B C=$ Red Blood Cell counts, $A L B=$ Albumin, $W B C=$ White Blood Cell count

LCT treated rats. There was no significant difference $(P=.05)$ in albumin between the control and LCT treatments.

\subsection{Histopathological Examination}

Result from observations conducted on the liver revealed a slightly enlarged liver, thinning of hepatic cord, vacuolar change of hepatocytes, random foci of single-cell, hepato-cellular necrosis and hyperplasia of kupffer cells in all LCT treated rats which became more obvious with increase in LCT dose. The section of the control liver generally exhibited no visible lesion on close observation (Fig. 2)

Kidneys of lambda-cyhalothrin treated Rattus norvegicus showed cloudy swelling of tubular epithelial cells, congestion of interstitial blood vessels and flattened epithelium in the renal cortex when compared with the control. These also became more conspicuous with increase in concentration of lambda-cyhalothrin in the examined kidney. The control kidneys appeared normal with no gross visible lesions and necrosis (Fig. 3).

\section{DISCUSSION}

This present study showed that exposure/ oral administration of Lambda cyhalothrin at varying concentrations of $100,75,50$ and $25 \mathrm{mg} / \mathrm{kg}$ for five weeks to male Wistar rats induced body weight loss, reduction in the white blood cell count and hemoglobin, and deleterious effects on the liver and kidney organs.

There was a significant decrease in weight of all LCT treated rats with $100 \mathrm{mg} / \mathrm{kg}$ LCT recording the highest weight loss. This is often associated with pesticide toxicity. 


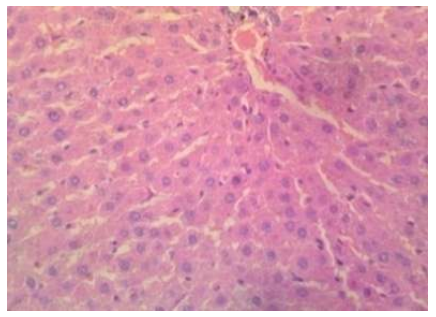

A

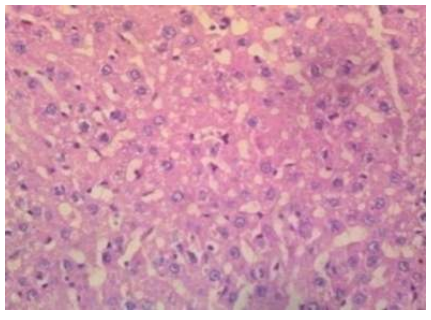

B

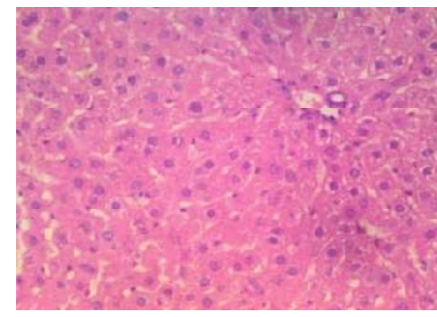

C

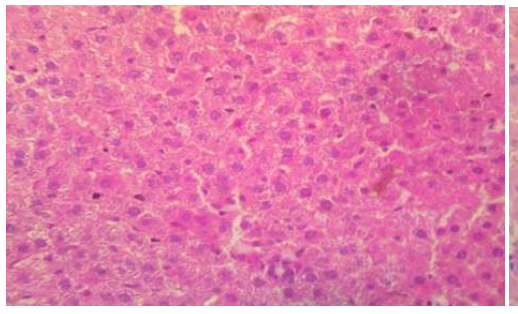

D

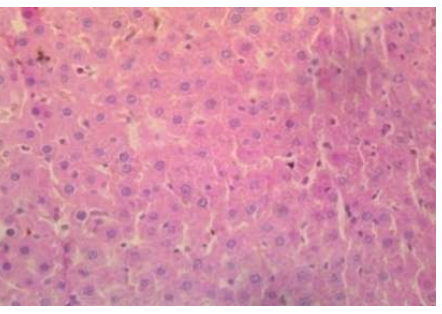

E

Fig. 2. Histological section of liver of Rattus norvegicus

A- $100 \mathrm{mg} / \mathrm{kg}$ Few foci of moderate thinning of hepatic cords, multiple foci of mild vacuolar changeof hepatocytes. There were a few random foci of single-cell hepatocellular necrosis. B- $75 \mathrm{mg} / \mathrm{kg}$. Few foci of moderate thinning of hepatic cords, multiple foci of mild vacuolar changeof hepatocytes. There are a few random foci of single-cell hepatocellular necrosis. C- $50 \mathrm{mg} / \mathrm{kg}$. Hepatic plates closely-packed with few foci of mild vacuolar change of hepatocytes. D- $25 \mathrm{mg} / \mathrm{kg}$. The hepatic plates were closely-packed. No visible lesion. E-

Control. The hepatic plates are closely-packed. H\& E Magnification x400

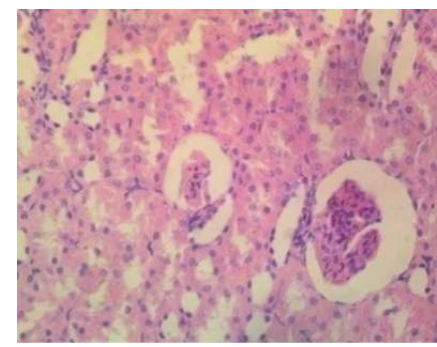

A

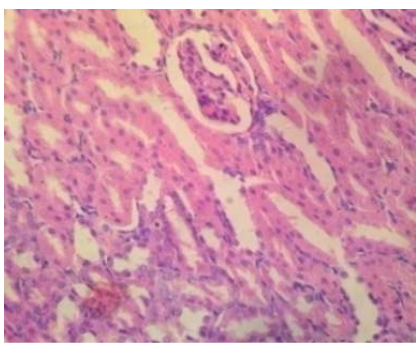

B

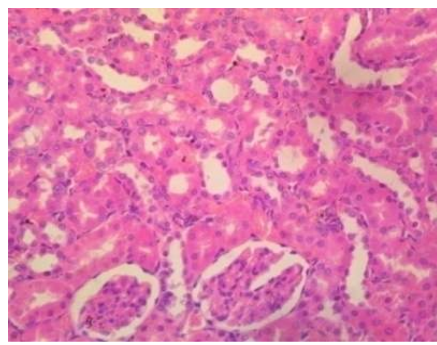

C

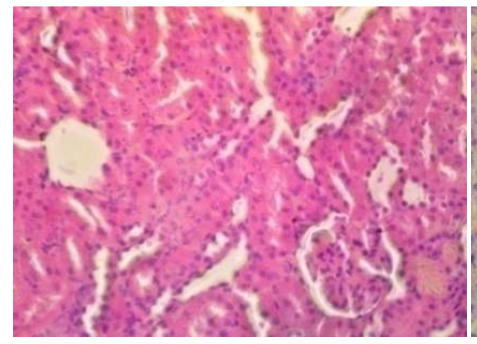

D

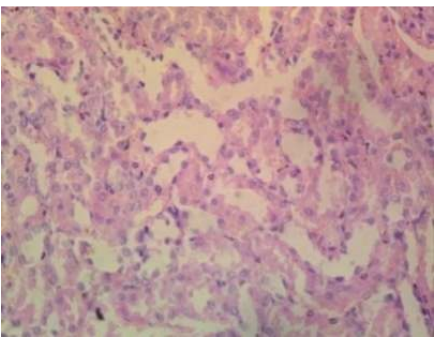

E

Fig. 3. Histological section of kidney of Rattus norvegicus

A- $100 \mathrm{mg} / \mathrm{kg}$. Few foci of mild cloudy swelling of tubular epithelial cells. B- $75 \mathrm{mg} / \mathrm{kg}$. Moderate congestion of renal interstitial blood vessels. No visible lesion (NVL) with glomeruli and tubules. $C-50 \mathrm{mg} / \mathrm{kg}$. Moderate congestion of renal interstitial blood vessels. NVL with glomeruli and tubules. $D-25 \mathrm{mg} / \mathrm{kg}$. There was mild congestion of interstitial blood vessels. NVL with glomeruli and tubules. E-Control. No Visible Lesion; normal glomeruli, tubules and renal interstitium. H\& E Magnification x400 
The liver is one of the largest organs and carries out the most complex biological function in the body. It secretes bile, synthesizes proteins, metabolizes nutrients, hormones and drugs and detoxifies noxious endogenous and exogenous substrate. Any toxic substance entering the body, such as LCT, would undergo biochemical transformation in the liver where it is detoxified by being metabolized. Overloading of the detoxification pathways leads to a build-up of toxins in the body leading to higher levels of free radicals, excess of which may damage the liver cells [17].

The Sub-chronic exposure of the rats to lambdacyhalothrin resulted in the alteration of the micro anatomy of the liver. This alteration included vacuolar changes of hepatocytes and hepatocellular necrosis, and becomes more conspicuous with increase in LCT concentration. Also, the micro anatomy of the kidney was altered with cloudy swelling of tubular epithelial cells, congestion of interstitial blood vessels although there were no visible lesions in both the liver and kidney. This is in line with findings of [18] who recorded adverse changes in liver tissues of test animals that have been treated with cypermethrin. [10] Also revealed was a significant increase in weight of kidney of rats treated with synthetic pyrethroid (cypermethrin).

The experiment showed significant dose dependent decrease in white blood cell counts, red blood cell counts and hemoglobin with increase in concentration of LCT. This conforms to the work of [19] who reported that oral ingestion of lambda-cyhalothrin significantly decreased the count of RBCs and WBCs content of treated rat relative to control and this probably explains the effect of lambda cyhalothrin on the erythropoiesis and the destruction of cells. This decrease in the WBC could leads to reduced body system immunity, anemic conditions and other health challenges in animals exposed to LCT.

The elevated Eosinophil (which was produced by the white blood cell for combating infections/toxin in the body) level recorded in the treated rats when compared with the control is an indication of the toxicity of LCT.

\section{CONCLUSION}

The experiment suggested a dose-dependent toxicity on the selected parameters. Lambdacyhalothrin is highly toxic (even at the lowest dose in this experiment) and may cause cell damage, organ failure, anaemic conditions and reduce immunity upon continuous exposure thereby affecting the overall health and wellbeing of the LCT- treated animals.

\section{ETHICAL ISSUE}

All animals were handled in accordance with the guidelines for care and use of laboratory animals as well as specific national laws where applicable.

\section{COMPETING INTERESTS}

Authors have declared that no competing interests exist.

\section{REFERENCES}

1. Mostafalou S, Abdollahi M. Concerns of environmental persistence of pesticides and human chronic diseases. Clin Exp Pharmacol. 2012;(3):1000-108.

2. Elliott M. Properties and applications of pyrethroids. Env. Health Perspec. 1976;14: 3-13.

3. Amweg EL, Weston DP. Use and toxicity of pyrethroid pesticides in the Central Valley, California, USA. Environ Toxicol Chem. 2005;24:1300-1301.

4. Oros DR, Werner I. Pyrethroid insecticide: An analysis of use pattern, distribution, potential toxicity and fate in the sacramento. San Joaquin Delta and Central Valley. White paper for the interagency ecological program. SFEI contribution 415. San Francisco Estuary Institute, Oakland, CA; 2005.

5. He LM, Troiano J, Wang A, Goh K. Environmental Chemistry, Ecotoxicity, and Fate of Lambda Cyhalothrin. Review of Environmental Contamination and Toxicology; 2008.

6. Anadon A, Martinez M, Martinez MA, Diaz MJ, Martinez-Larranaga MR. Toxicokinetics of lambda-cyhalothrin in rats. Toxicol Lett. 2006;1:165(1):47-56.

7. Ratnasooriya WD, Ratnayake SS, Jayatunga YN. Effects of Icon, a pyrethroid insecticide on early pregnancy of rats. Hum Exp Toxicol. 2003;22(10):52333.

8. Kidd H, James DR. The agrochemicals handbook, $3^{\text {rd }}$ edition. Royal society of Chemistry Information Services, Cambridge, UK; 1991. 
9. Meister RT. (ed). Farm chemicals handbook '92. Meister Publishing co. Willoughby, OH; 1992.

10. Sangha GK, Kamelpreet K, Khera KS, Balwinder $S$. Toxicological effects of cypermethrin on female albino rats. Toxicol. International. 2011;18(1):5-8.

11. Oshoke $\mathrm{FI}$, Fadina OO, Fayinminnu 00. Sub-chronic toxicity study of synthetic Pyrethroids (lambda-cyhalothrin) on reproductive organs of male wistar rats. International Journal of Advance Agricultural Research. 2016;4:38-45.

12. Fadina OO, Taiwo VO, Ogunsanmi AO. Single and repetitive oral administration of common pesticides and alcohol on rabbits. Trop. Vet. 1999;17:97-106.

13. Hayat M. Principles and techniques of electron microscopy, biological applications. $3^{\text {rd }}$ ed. CRC Press; 1989.

14. Bancroft JD, Gamble M. Theory and practice of histological techniques; 2002.
15. Avwioro OG. Histochemistry and tissue pathology: Principles and techniques. $1^{\text {st }}$ ed. Nigeria: Claverianum Press; 2010.

16. Duncan DB. Multiple range and multiple $F$ tests. Biometrics. 1955;11:1-42.

17. Carbot I. The liver cleaning diet; 2003.

(Accessed 10 August 2012)

Available: http//www.liverdoctor.com

18. Elbeitha A, Daas SI, Khamas W, Darmani $\mathrm{H}$. Evaluation of toxic potentials of cypermethrin pesticides on some reproductive and fertility parameters in male rats. Arch Environ Contam Toxicol. 2001;41:522-528.

19. Dahamna $S$, Belguet A, Bouamra D, Guendouz A, Mergham M. and Harzallah D. Evaluation of the toxicity of cypermethrin pesticide on organs weight loss and some biochemical and histological parameters. Commun. Agric. Appl. Biol. Sci. 2011;76(4):915-921.

(c) 2017 Fadina et al.; This is an Open Access article distributed under the terms of the Creative Commons Attribution License (http://creativecommons.org/licenses/by/4.0), which permits unrestricted use, distribution, and reproduction in any medium, provided the original work is properly cited.

Peer-review history:

The peer review history for this paper can be accessed here: http://sciencedomain.org/review-history/19737 